\title{
Genetic susceptibility to the respiratory effects of air pollution
}

\author{
I A Yang, ${ }^{1,2}$ K M Fong, ${ }^{1,2}$ P V Zimmerman, ${ }^{1,2}$ S T Holgate, ${ }^{3}$ J W Holloway ${ }^{3,4}$
}

${ }^{1}$ School of Medicine, The University of Queensland, The Prince Charles Hospital, Brisbane, Australia;

${ }^{2}$ Department of Thoracic Medicine, The Prince Charles Hospital, Brisbane, Australia;

${ }^{3}$ Infection, Inflammation and Repair Division, University of Southampton, Southampton, UK; ${ }^{4}$ Human Genetics Division School of Medicine, University of Southampton, Southampton, UK

Correspondence to:

Dr I Yang, Department of Thoracic Medicine, The Prince Charles Hospital, Rode Road, Chermside, Brisbane QLD 4032, Australia; lan_Yang@ health.qld.gov.au

Received 8 February 2007 Accepted 9 May 2007

\section{ABSTRACT}

There is large variation between individuals in their response to air pollutants. This review summarises the existing evidence that genetic factors influence the mechanisms of lung injury caused by air pollutants. Genetic association studies have compared the adverse effects of air pollutants between subjects with specific genotypes in biologically relevant genes. In human studies of ozone exposure, polymorphisms in oxidative stress genes (N001, GSTM1, GSTP1) modify respiratory symptoms, lung function, biomarkers and risk of asthma. Inflammatory gene polymorphisms (TNF) influence the lung function response to ozone, and the effect of different levels of ozone on the development of asthma. Polymorphisms in oxidative stress genes (GSTM1, GSTP1) alter the response to combined exposure to ragweed pollen and diesel exhaust particles. Importantly, polymorphisms in an oxidative stress gene (GSTM1) have predicted patients with asthma who benefit from antioxidant supplementation in Mexico City, which has chronically high ozone exposure. Genetic linkage studies of families have not been feasible for studying the effects of air pollution in humans, but some progress has been made with pedigrees of specially bred mice, in identifying chromosomal regions linked to effects of ozone or particles. A high priority now, in addition to avoiding exposure in the most susceptible people, is to clearly identify the most effective and safe chemopreventive agents for individuals who are genetically susceptible to the adverse effects of air pollution (eg, antioxidants to be taken during high ozone levels).

\section{ADVERSE HEALTH EFFECTS OF AIR POLLUTANTS}

Despite improvement in air quality in the past few decades, adverse health effects from air pollution remain important. ${ }^{2}$ It has been estimated that exposure to air pollution contributes to $6 \%$ of total mortality. ${ }^{3}$ Of concern, vehicle exhaust emissions are increasing worldwide and exposure to traffic related air pollution has been associated with cardiorespiratory mortality. ${ }^{4}$ However, the exact mechanisms of injury of the major air pollutantsparticulate matter, ozone and nitrogen dioxideare not yet fully understood. Furthermore, there is documented interindividual variability in the adverse health effects of air pollutants. Consequently, the identification of subgroups of the population who are particularly vulnerable to air pollution is an important objective. This review presents evidence that genetic factors influence the mechanisms of lung injury caused by air pollutants.

\section{Interindividual variability in the respiratory effects of air pollutants}

Although overall effects are seen in the population as a whole, there is clearly interindividual variability in the adverse health effects of air pollutants. Certain groups within the population are more vulnerable, including the young and the elderly. ${ }^{56}$ Even in healthy adults who have undergone controlled exposure to an air pollutant, there is much variability in the measured effects. For example, while the lung function and proinflammatory effects of ozone exposure are reproducible within an individual, large variation in response exists between individuals. ${ }^{78}$ Identifying the factors that influence this variability would help to recognise at-risk groups who would benefit the most from preventive strategies. Furthermore, identification of at-risk groups, the degree of their sensitivity to exposure and their frequency in the population, will aid in the cost-benefit analysis of "safe" exposure levels in the public health setting. Various factors have been examined as determinants of this variability, including climatic conditions, dose and time of exposure to air pollutant, age, gender, diet and presence of lung disease. ${ }^{9}$ In addition, genetic factors are likely to be important, especially given that processes involved in the response to air pollutants-oxidative stress and inflammation-are known to be under genetic regulation. ${ }^{9} 10$

\section{APPROACHES TO STUDYING GENETIC VARIATION AND AIR POLLUTION}

Two approaches to identifying genes of importance to disease are genetic linkage studies of families and candidate gene association studies. ${ }^{11-13}$

\section{(i) Genetic linkage studies of families}

Genetic linkage studies identify chromosomal regions that show genetic linkage with a certain disease or disease trait in families. This approach requires no prior hypothesis of which genes are implicated, and therefore has the potential to discover novel disease genes. To date, genetic linkage studies have only been applied to animal models of response to air pollution, in which mice are specially bred to be susceptible or resistant to the effects of specific air pollutants. ${ }^{9}{ }^{10}$ No genetic linkage studies have been feasible in relation to air pollution in human families, because of the difficulty in defining adverse effects to air pollution exposure in different generations.

\section{(ii) Genetic association studies}

Genetic association studies of susceptibility to air pollution compare the adverse effects of air 
pollutants between subjects with different genotypes in biologically relevant genes. Possible candidate genes should ideally encode proteins involved in biological pathways related to responses to air pollution (eg, cough, sputum production, bronchoconstriction, airway inflammation). A number of genetic association studies have now been performed in human populations in relation to such responses to air pollution (table 1), studying candidate genes mainly involved in antioxidant defences and inflammation (as described in detail below).

\section{Study design issues in genetic studies of air pollution}

The ultimate aim of genetic studies is to identify and/or provide supporting evidence that a given genetic polymorphism is "causal" in the development of a disease or disease trait. This requires proof of consistency and strength of association, biological plausibility and dose-response relationship. ${ }^{14}$ Thus a broad range of multidisciplinary studies is required in environmental genomics. Human genetic studies have the potential to confirm and complement evidence from epidemiological studies,

Table 1 Genetic association studies of air pollution

\begin{tabular}{|c|c|c|c|c|c|c|}
\hline Study & Study design & Population & Gene & $\begin{array}{l}\text { Environmental } \\
\text { exposure }\end{array}$ & Phenotype & Outcome \\
\hline \multicolumn{7}{|l|}{ Ozone } \\
\hline Bergamaschi $2001^{58}$ & Case control & $\begin{array}{l}\text { Italy-24 healthy } \\
\text { adults }\end{array}$ & $\begin{array}{l}\text { N001, } \\
\text { GSTM1 }\end{array}$ & $\begin{array}{l}\text { Ozone: ambient } \\
\text { exposure during } \\
\text { exercise }\end{array}$ & $\begin{array}{l}\mathrm{FEV}_{1} \text {, serum } \mathrm{CC} 16 \\
\text { ROS-DNA adducts }\end{array}$ & $\begin{array}{l}\text { N001 Pro/Pro187 and GSTM1-null individuals had } \\
\text { decreased FEV } \text {, increased CC16 and increased }_{\text {ROS-DNA with ozone }>80 \mathrm{ppb} \text {. }}\end{array}$ \\
\hline Corradi $2002^{59}$ & Case control & $\begin{array}{l}\text { Italy-22 healthy } \\
\text { adults }\end{array}$ & $\begin{array}{l}\text { No01, } \\
\text { GSTM1 }\end{array}$ & $\begin{array}{l}\text { Ozone: controlled } \\
\text { inhalation during } \\
\text { exercise }\end{array}$ & $\begin{array}{l}\text { Lipid peroxidation } \\
\text { products in exhaled } \\
\text { breath condensate }\end{array}$ & $\begin{array}{l}\text { N001 Pro/Pro187 and GSTM1-null individuals had } \\
\text { biomarkers of oxidative stress with ozone } \\
\text { exposure. }\end{array}$ \\
\hline Otto-Knapp $2003^{60}$ & Ex vivo & $\begin{array}{l}\text { Germany-20 } \\
\text { adults undergoing } \\
\text { nasal surgery }\end{array}$ & GSTM1 & $\begin{array}{l}\text { Ozone: controlled } \\
\text { laboratory exposure } \\
\text { to nasal biopsies }\end{array}$ & SOD activity & $\begin{array}{l}\text { Nasal biopsies of GSTM1-null individuals had } \\
\text { increased SOD activity with ozone exposure. }\end{array}$ \\
\hline David $2003^{62}$ & Case control & $\begin{array}{l}\text { Mexico-225 } \\
\text { parent-asthmatic } \\
\text { child trios }\end{array}$ & $\begin{array}{l}\text { No01, } \\
\text { GSTM1 }\end{array}$ & $\begin{array}{l}\text { Ozone: ambient } \\
\text { exposure }\end{array}$ & Asthma & $\begin{array}{l}\text { NQ01 Ser187 and GSTM1-null children had } \\
\text { reduced risk of asthma (RR 0.4). }\end{array}$ \\
\hline Romieu $2004^{63}$ & $\begin{array}{l}\text { Randomised } \\
\text { controlled trial }\end{array}$ & $\begin{array}{l}\text { Mexico-158 } \\
\text { asthmatic } \\
\text { children }\end{array}$ & GSTM1 & $\begin{array}{l}\text { Ozone: ambient } \\
\text { exposure } \pm \\
\text { antioxidant } \\
\text { supplementation }\end{array}$ & $\mathrm{FEF}_{25-75}$ & $\begin{array}{l}\text { Asthmatic children on placebo with GSTM1-null } \\
\text { genotype had decreased } \mathrm{FEF}_{25-75} \text { per } 50 \text { ppb } \\
\text { ozone (vs no change in } \mathrm{FEF}_{25-75} \text { in GSTM1-positive } \\
\text { children on placebo, or any children on antioxidant } \\
\text { supplement). }\end{array}$ \\
\hline Romieu $2006^{64}$ & $\begin{array}{l}\text { Randomised } \\
\text { controlled trial }\end{array}$ & $\begin{array}{l}\text { Mexico-151 } \\
\text { asthmatic } \\
\text { children }\end{array}$ & $\begin{array}{l}\text { GSTM1, } \\
\text { GSTP1 }\end{array}$ & $\begin{array}{l}\text { Ozone: ambient } \\
\text { exposure } \pm \\
\text { antioxidant } \\
\text { supplementation }\end{array}$ & $\begin{array}{l}\text { Respiratory } \\
\text { symptoms }\end{array}$ & $\begin{array}{l}\text { GSTM1-null and GSTP1 Val/Val individuals had the } \\
\text { greatest increase in respiratory symptoms per } \\
20 \text { ppb ozone. }\end{array}$ \\
\hline Yang $2005^{65}$ & Case control & $\begin{array}{l}\text { Germany-51 } \\
\text { adults undergoing } \\
\text { ozone challenge }\end{array}$ & $\begin{array}{l}\text { TNF, TLR4, } \\
\text { SOD2, GPX1 }\end{array}$ & $\begin{array}{l}\text { Ozone: controlled } \\
\text { inhalation during } \\
\text { exercise }\end{array}$ & $\mathrm{FEV}_{1}$ & $\begin{array}{l}\text { Mean fall in } \mathrm{FEV}_{1} \text { with ozone challenge was } \\
\text { greatest in } T N F-308 \mathrm{G} / \mathrm{G} \text { individuals. }\end{array}$ \\
\hline Li $2006^{66}$ & Case control & $\begin{array}{l}\text { USA-3699 } \\
\text { children }\end{array}$ & $\begin{array}{l}\text { TNF, GSTM1, } \\
\text { GSTP1 }\end{array}$ & $\begin{array}{l}\text { Ozone: ambient } \\
\text { exposure }\end{array}$ & Asthma, wheezing & $\begin{array}{l}\text { TNF }-308 \mathrm{G} / \mathrm{G} \text { protected against asthma and } \\
\text { wheezing in children living in lower ozone } \\
\text { communities. Effect was increased with GSTM1- } \\
\text { null and GSTP1 Ile/lle. }\end{array}$ \\
\hline \multicolumn{7}{|l|}{ Particulate matter } \\
\hline Gilliland $2004^{88}$ & Case control & $\begin{array}{l}\text { USA-19 ragweed } \\
\text { sensitive adults }\end{array}$ & $\begin{array}{l}\text { GSTM1, } \\
\text { GSTP1 }\end{array}$ & $\begin{array}{l}\text { Diesel exhaust } \\
\text { particles and } \\
\text { ragweed allergen: } \\
\text { controlled nasal } \\
\text { challenge }\end{array}$ & $\begin{array}{l}\text { Nasal IgE, } \\
\text { histamine, IL4, } \\
\text { IFN } \gamma\end{array}$ & $\begin{array}{l}\text { GSTM1-null and GSTP1 lle/lle individuals had the } \\
\text { greatest response to ragweed with DEP exposure. }\end{array}$ \\
\hline Gilliland $2006^{89}$ & Case control & $\begin{array}{l}\text { USA-19 ragweed } \\
\text { sensitive adults }\end{array}$ & $\begin{array}{l}\text { GSTM1, } \\
\text { GSTP1 }\end{array}$ & $\begin{array}{l}\text { Diesel exhaust } \\
\text { particles, ragweed } \\
\text { allergen and } \\
\text { secondhand smoke: } \\
\text { controlled nasal } \\
\text { challenge }\end{array}$ & $\begin{array}{l}\text { Nasal IgE, } \\
\text { histamine, IL4, } \\
\text { IFN } \gamma\end{array}$ & $\begin{array}{l}\text { GSTM1-null and GSTP1 lle/lle individuals had the } \\
\text { greatest response to ragweed, after secondhand } \\
\text { smoke exposure. }\end{array}$ \\
\hline \multicolumn{7}{|l|}{ Sulphur dioxide } \\
\hline Winterton $2001^{67}$ & Case control & $\begin{array}{l}\text { USA-58 } \\
\text { asthmatic adults }\end{array}$ & $\begin{array}{l}T N F \\
A D R B 2 \\
\text { IL4, CC16, } \\
\text { LTA }\end{array}$ & $\begin{array}{l}\text { Sulphur dioxide: } \\
\text { controlled } \\
\text { inhalation during } \\
\text { exercise }\end{array}$ & $\mathrm{FEV}_{1}$ & $\begin{array}{l}T N F-308 \mathrm{G} / \mathrm{G} \text { was associated with being a } \\
\text { responder to } \mathrm{SO}_{2} \text {. No association was observed } \\
\text { between other genotypes and } \mathrm{FEV}_{1} \text { response to } \\
\mathrm{SO}_{2} \text {. }\end{array}$ \\
\hline
\end{tabular}


toxicological experiments and animal genetic models. In planning for genomic research in air pollution, a number of important methodological issues need to be considered, including selection of candidate genes, selection of exposures and phenotypes, and design of genetic epidemiology studies. ${ }^{15}$

\section{Translational studies}

A number of issues arise with respect to the applicability of animal models of genetic susceptibility to human disease. The similarity (homology) between mouse and human genes often allows information about candidate genes in mice to be directly translated to humans ${ }^{9}$ but this does not always hold true. In addition, the relevance to humans of the biological phenotypes in mice needs to be assessed. Other considerations include whether polymorphisms in different strains of mice have biological significance. Thus although further validation of candidate genes is required, genome-wide scans in animal models have so far been successful in identifying chromosomal regions linked to the effects of inhaled air pollutants, and proposing novel candidate genes involved in mechanisms of lung injury from air pollution.

\section{Selection of candidate genes and polymorphisms}

Prioritising polymorphisms for candidate gene studies is critical. ${ }^{16}$ The most common causes of Mendelian diseases are polymorphisms leading to a change in amino acid (ie nonsynonymous substitutions leading to a missense or nonsense mutations). Clinical severity in Mendelian diseases appears to be greater with more radical amino acid replacements. ${ }^{16}{ }_{17}$ However, in the general population, variations within protein coding sequences (exons) represent $<1 \%$ of polymorphisms. ${ }^{18}$ Most polymorphisms actually occur in non-coding regions such as introns (intervening between protein coding sequences), regulatory regions (that control gene expression, eg, promoter, $3^{\prime}$-untranslated region) or intergenic regions. Variations in these non-coding regions are now coming under greater scrutiny in multifactorial diseases. To be systematic, candidate gene studies should analyse tagging single nucleotide polymorphisms (SNPs) (maximally informative SNPs in a region of high linkage disequilibrium) and haplotypes (combinations of alleles within a gene) of relevant genes across the whole pathway of each mechanism of pathogenesis. ${ }^{16}{ }^{19}$ This would provide important information about which polymorphisms in the pathway are causal. Selection of genes for study could be made based on genetic linkage results in animal models, and on pathways implicated in experimental models of cellular exposure to air pollutants.

\section{Selection of air pollutants and phenotypes}

The choice of air pollutants and phenotypes related to exposure (eg, physiological phenotypes such as symptoms and lung function changes and biological phenotypes, including airway inflammation and oxidative stress) will influence the clinical relevance, statistical power and feasibility of genetic studies. Overlap between the effects of individual air pollutants needs to be considered, ${ }^{20}$ especially since pollutants are commonly found as complex mixtures at ground level. An in vitro example of interaction of air pollutants is the enhanced adhesion of particles to bronchial epithelium by simultaneous exposure to ozone or cigarette smoke. ${ }^{21}$ Also, microbial products attached to particulate matter and organic components of diesel exhaust particles contribute substantially to the proinflammatory activation of alveolar macrophages. ${ }^{22}{ }^{23}$ Air pollutants generate reactive oxygen species, leading to an oxidative stress response, which is an important phenotype. Furthermore, different genes may be involved in different air pollutant response phenotypes. A single polymorphism in a single gene is unlikely to explain variation in all phenotypes, but rather a complex interaction of genes will probably determine response. This is due to the likely relatively small functional effects of individual polymorphisms within complex biological pathways. ${ }^{24}$

\section{Genetic epidemiological issues}

A number of methodological considerations should be addressed when designing and interpreting future genetic studies of air pollution. Replication of positive findings remains an important issue for genetic association studies. ${ }^{25}$ When meta-analysis of studies is performed, it has been suggested that perhaps $20-30 \%$ of genetic association studies published in complex multifactorial diseases are truly statistically significant. ${ }^{26} 27$ While biological heterogeneity between populations may explain discordant results, more important factors are inadequate power, chance and publication bias. ${ }^{28}$ To circumvent these problems, large scale, well designed studies are required, ${ }^{13}{ }^{29}$ in order to detect modest genetic effects including gene-gene and gene-environment interaction. For categorical outcomes, power calculations would need to consider allele frequency, ratio of cases to controls and the size of a clinically important odds ratio to be detected. ${ }^{30}$ In disease susceptibility studies, depending on the minor allele frequency of the SNP of interest, the sample size required may range from many hundreds (of cases and controls) to thousands, such as the British cohort study of asthma and $\beta_{2}$-adrenoceptor polymorphisms. ${ }^{31}$ For continuous outcomes, the allele frequency, standard deviation of the phenotype of interest and the size of a clinically or biologically important difference should be considered. The recent introduction of genome-wide association studies (using SNP chips) further highlights the need for robust study design.

In the following section, we will review the genetic linkage studies in mice, and genetic association studies of variation in response to air pollution in humans, in light of these study design issues.

\section{OZONE}

\section{Mechanisms of response to ozone}

Ozone $\left(\mathrm{O}_{3}\right)$ is a gaseous air pollutant generated by sunlight from hydrocarbons and nitrogen oxides produced in vehicle exhaust. Increased outdoor levels of ozone have been associated with an increased risk of admissions for asthma and chronic obstructive pulmonary disease (COPD) and increased mortality in patients with asthma and the general population. ${ }^{32-37}$ Only one study, performed in California, has shown a relationship between the incidence of asthma and ozone exposure in children undertaking heavy exercise in high ozone concentrations. ${ }^{38}$

In studies of human volunteers, controlled inhalation of ozone causes acute changes in lung function, infiltration of neutrophils into the airways and enhanced allergen induced bronchoconstriction. $^{839-41}$ Ozone exposure increases airway levels of inflammatory mediators (such as interleukin (IL)8, GRO- $\alpha$, P-selectin and intercellular adhesion molecule 1 (ICAM1)), and depletes levels of protective antioxidants (ascorbate and glutathione peroxidase) in bronchoalveolar lavage fluid (BALF). ${ }^{42-45}$ Ozone is a strong oxidant and reacts with the epithelial lining fluid to generate free radicals. ${ }^{46}$ In vitro exposure of bronchial epithelial cells to ozone increases the production of 
inflammatory mediators (IL6, IL8, ICAM-1, granulocyte macrophage-colony stimulating factor (GM-CSF), RANTES and tumour necrosis factor $\alpha(\mathrm{TNF} \alpha)$ ). ${ }^{47-49}$ Thus oxidative stress and inflammation are involved in the pulmonary response to ozone exposure.

\section{Genetic linkage studies of ozone exposure in mice}

Genome wide scans in mice have found genetic linkage with the effects of ozone exposure. ${ }^{50}$ Using genetic markers spaced across the genome, regions on mouse chromosomes 17 and 11 were found to be linked to neutrophil infiltration into the airways, an ozone induced phenotype. ${ }^{51}$ Genes included in these chromosomal regions encoded proteins involved in inflammation and oxidative stress (TNF $\alpha$, mast cell proteases, manganese superoxide dismutase). Subsequent experiments in mice showed that blocking the function of TNF $\alpha$, either with anti-TNF $\alpha$ antibody or genetic deletion of TNF receptor, reduces response to ozone, further supporting the importance of this cytokine in mechanisms of injury. ${ }^{51-53}$

Chromosomes 17 and 11 were also linked to acute lung injury, pulmonary oedema and death in mice after exposure to high concentrations of ozone. ${ }^{54}$ Candidate genes in these regions included antioxidant genes (xanthine dehydrogenase) and inflammatory genes (nitric oxide synthase, myeloperoxidase and small soluble cytokines). ${ }^{545} \mathrm{~A}$ different ozone induced phenotype, lung hyperpermeability, has been linked to mouse chromosome 4 which contains the gene for the pattern recognition receptor, Toll-like receptor 4 (T/r4) ${ }^{56}{ }^{57}$ In these studies, C3 and OuJ mice strains were used, which differ by a polymorphism in the mouse Tlr4 gene which reduces endotoxin responsiveness in the C3 strain. The C3 strain has reduced lung hyperpermeability to ozone, indicating that polymorphisms in the innate immune response pathway may influence susceptibility to ozone..$^{10}$ This is an example of where polymorphisms in mouse models may provide candidates for testing in humans.

\section{Genetic association studies of ozone exposure in humans} Ozone response and oxidative stress genes

Polymorphisms in two metabolising enzymes have been associated with the effects of ozone exposure in human studies: an enzyme that produces hydroquinones that may react with ozone to reactive oxygen species $(\mathrm{NAD}(\mathrm{P}) \mathrm{H}$ :quinone oxidoreductase 1, NQO1), and a detoxification enzyme that reduces oxidative stress (glutathione-S-transferase M1, GSTM1). When ozone is inhaled, it reacts with substrates in the epithelial lining fluid (eg, hydroquinones, formed from quinones by the enzyme NQO1), to produce reactive oxygen species, which are potentially damaging to the lung. A polymorphism is present in the NQO1 gene in exon 6, leading to a substitution at amino acid 187 of proline to serine. The proline form of the NOO1 enzyme is resistant to degradation, making it more active than the serine form. With increased NOO1 enzyme activity, there is more reaction with ozone and greater build-up of reactive oxygen species. If there is also a deletion of the GSTM1 gene (null genotype), leading to impaired detoxification of reactive oxygen species, then this combination of polymorphisms (high production of reactive oxygen species and impaired detoxification) confers a high risk of oxidative stress from ozone.

In a study of ozone exposure, 24 healthy non-smokers performed bicycle rides for $2 \mathrm{~h}$ outdoors. ${ }^{58}$ When the ozone concentration was high $(>80 \mathrm{ppb})$, subjects with the high oxidant producing genotypes (NQO1 Pro/Pro187 and GSTM1null, $\mathrm{n}=8$ ) had a greater fall in forced expiratory volume in $1 \mathrm{~s}$
$\left(\mathrm{FEV}_{1}\right)$, and increased airway epithelial damage, as measured by serum CC16, compared with subjects without this genotype. Subjects with susceptible genotypes also sustained excessive DNA damage by reactive oxygen species, as shown by an increase in the biomarker $8-\mathrm{OHdG} .^{58}$ These results were confirmed in a second study, in which ozone exposure during exercise resulted in higher levels of oxidative stress (lipid peroxidation products) in subjects with susceptible genotypes. ${ }^{59}$ Similarly, a laboratory study of ozone exposure to human nasal mucosal biopsies showed that subjects with absent GSTM1 function had increased activity of the antioxidant enzyme, superoxide dismutase, to counter higher levels of oxidative stress. ${ }^{60}$ Taken together, these studies provide evidence for genetically predetermined depletion of antioxidant enyzme function as a predisposing factor for susceptibility to ozone. This parallels the interaction of oxidative stress genes with other environmental agents such as smoking. ${ }^{61}$

Several genetic studies of asthma have been performed in Mexico City, where outdoor concentrations of ozone are high throughout the year, providing an opportunity to study chronic ozone exposure. In a study of children with asthma, an association was observed between polymorphisms in the oxidative stress genes, NQO1 and GSTM1, and the development of asthma. ${ }^{2}$ Furthermore, a clinical trial showed that children with asthma with the low antioxidant GSTM1 genotype had a fall in lung function with increasing ozone concentration, unless protected by antioxidant supplementation with vitamins $\mathrm{C}$ and $\mathrm{E}^{6{ }^{6}}$ Increase in breathing difficulty was also seen in children with asthma with oxidative stress risk genotypes (GSTM1 null and GSTP1 Val/Val). ${ }^{64}$ These results provide evidence for the notion of targeted chemoprevention for patients with asthma who are genetically susceptible to the adverse respiratory effects of ozone.

\section{Ozone response and inflammatory genes}

Polymorphisms in the gene for the proinflammatory cytokine TNF $\alpha$ have been associated with the adverse effects of air pollutants in several studies. We performed a genetic association study of TNF polymorphisms and ozone exposure in 51 participants who inhaled ozone during intermittent exercise. ${ }^{65}$ With ozone challenge, there was a statistically significantly greater fall in $\mathrm{FEV}_{1}$ (-9\% of baseline) in individuals with the TNF -308G/G genotype, compared with subjects with the $-308 \mathrm{G} / \mathrm{A}$ or A/A genotypes ( $-3 \%$ of baseline). A similar association was found when combinations of polymorphisms (haplotypes) in the TNF gene were analysed. Specifically, the LTA +252G/TNF -1031T/TNF -308A/TNF -238G haplotype conferred the smallest change in $\mathrm{FEV}_{1}$ with ozone exposure. In an epidemiological study of 1123 children, the TNF -308G/G genotype reduced the risk of wheezing, an effect that was greater in communities with the lowest ozone concentrations. This protective effect was reduced in subjects with GSTM1-null and GSTP1 Ile/lle genotypes. ${ }^{66}$ Thus there is preliminary evidence that the human TNF gene is a factor for susceptibility to ozone exposure, which extends the findings in animal models (mouse thf gene associated with ozone effects) ${ }^{51}$ and also parallels the involvement of the TNF gene in the response to sulphur dioxide ${ }^{67}$ (as discussed below). There was discordance in direction of effect, with the $T N F-308 \mathrm{G} / \mathrm{G}$ genotype being associated with a greater fall in $\mathrm{FEV}_{1}$ with ozone (or sulphur dioxide) challenge, whereas this genotype was protective against wheezing in low ozone communities. This may reflect differences in study design (laboratory challenge vs epidemiological study) or patient population (adults vs children), or 
could be due to the TNF -308 polymorphism being in linkage disequilibrium with other SNPs in the TNF or nearby genes that may in fact be the functional polymorphism. ${ }^{68}$ Hence further clinical and biological investigations are needed to confirm the exact role of $T N F$ polymorphisms in response to ozone.

\section{PARTICULATE MATTER}

\section{Mechanisms of response to particulate matter}

Particulate matter (PM) is a mixture of solid and liquid particles whose deposition within the lung is determined by diameter. PM10 are coarse, "thoracic" particles $<10 \mu \mathrm{m}$ in diameter, PM2.5 are fine, "respirable" particles $<2.5 \mu \mathrm{m}$ and ultrafine particles are $<100 \mathrm{~nm} .{ }^{1}$ PM10 and PM2.5 have been associated with increased mortality, increased admission rates for respiratory diseases and decreased lung function in adults with COPD and children with asthma. ${ }^{6-73}$ Diesel exhaust particles form the major component of airborne particulate matter. ${ }^{74}$ Short term exposure to diesel exhaust particles produces systemic and pulmonary inflammation, enhances bronchial hyper-responsiveness in patients with asthma and increases sensitisation to airborne allergens. ${ }^{74}$ Inhalation of diesel exhaust particles increased airway inflammatory cells (neutrophils, mast cells and lymphocytes) and upregulated inflammatory mediators (adhesion molecules, IL8, IL13 and GRO- $\alpha$ ). ${ }^{75-78}$

Exposure of the bronchial epithelium to diesel exhaust particles generates reactive oxygen species and increases expression of a marker of oxidative stress, haeme oxygenase $1^{23} 79$ Oxidative stress induced by diesel exhaust particles promotes inflammation via activation of the transcription factors NF- $\mathrm{KB}$ and activator protein-1, and other processes implicated in inflammation, including histone acetylation and the MAPK pathway. ${ }^{80-83}$ In vitro studies have shown that diesel exhaust particles increase the production of inflammatory mediators (IL8, GM-CSF and ICAM-1) from human airway epithelial cells. ${ }^{84}{ }^{85}$ Thus evidence to date suggests that oxidative stress stimulates the proinflammatory response to particulate matter.

\section{Genetic linkage studies of particulate matter exposure in mice}

Several studies have also found genetic linkage with the effects of exposure to particulate matter. In mice exposed to acid sulphate coated particles, the phagocytic function of alveolar macrophages has been linked to mouse chromosomes 17, 13 and $11 .{ }^{86}$ Genes within these regions included those involved in inflammation (TNF $\alpha$, lymphotoxin $\alpha$, mast cell proteases, heat shock proteins) and oxidative stress (glutathione peroxidase). Interestingly, some of these regions and genes are in common with those linked to response to ozone exposure. Acute lung injury induced by nickel in a mouse model is linked to mouse chromosomes 6 (surfactant protein B) and 8 (metallothionein 1). ${ }^{87}$

\section{Genetic association studies of particulate matter exposure in humans}

In a genetic association study, subjects were challenged intranasally with ragweed allergen, with or without the presence of diesel exhaust particles. ${ }^{88}$ Those subjects with low antioxidant genotypes (GSTM1-null and GSTP1 Ile/lle) had enhanced nasal responses, as indicated by increased nasal IgE and histamine. ${ }^{88}$ These genotype specific responses to ragweed were also aggravated in the presence of secondhand smoke. ${ }^{89}$ These results suggest that genetically determined antioxidant defences modify the adverse effects of diesel exhaust particles and secondhand smoke during allergic responses. These studies also highlight that associations with a specific SNP may appear inconsistent at times. For example, in the GSTP1 Ile $>$ Val polymorphism, subjects with the Ile/lle genotype showed excessive response to allergens, ${ }^{88}{ }^{89}$ whereas subjects with the GSTP1 Val/Val genotype had increased adverse effects to ozone exposure. ${ }^{64}$ As discussed previously by others, ${ }^{64}$ differences in direction of effects with specific SNPs may be due to chance, insufficient power, different populations or ethnic origins, variations in study design and different phenotypes studied.

\section{NITROGEN DIOXIDE}

Nitrogen dioxide $\left(\mathrm{NO}_{2}\right)$ is formed by the reaction of ozone $\left(\mathrm{O}_{3}\right)$ with nitric oxide (NO) which is emitted from motor vehicles, power sources and, in the indoor environment, gas cookers. $\mathrm{NO}_{2}$ exposure has been linked with respiratory morbidity in epidemiology studies,${ }^{74}$ including asthma exacerbations. ${ }^{90}$ Interstrain variation in susceptibility to $\mathrm{NO}_{2}$ exposure was observed in a study of inbred mice, suggesting a significant genetic contribution. $^{91}$ There was discordance between the strains affected by $\mathrm{NO}_{2}$ and those affected by ozone in the same study, indicating that the mechanisms of injury may differ between these two air pollutants. ${ }^{91}$ To date, no human genetic linkage studies or association studies have been published for $\mathrm{NO}_{2}$.

\section{SULPHUR DIOXIDE}

Sulphur dioxide $\left(\mathrm{SO}_{2}\right)$ is a gas formed from the burning of coal and oil. Genetic determinants of variability in response to $\mathrm{SO}_{2}$ have been investigated in one association study. Sixty-one patients with asthma had controlled exposure to $0.5 \mathrm{ppm} \mathrm{SO}_{2}$

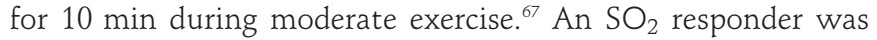
defined as having a $\geqslant 12 \%$ decrease in $\mathrm{FEV}_{1}$. The TNF - 308G/G genotype was significantly associated with being a responder (present in 12/12 of responders, compared with 28/46 of nonresponders). There were no associations observed with polymorphisms in the $\beta_{2}$ adrenoceptor, IL4 receptor, CC16 or lymphotoxin $\alpha$ genes. $^{67}$

\section{IMPLICATIONS OF GENETIC STUDIES OF RESPONSE TO AIR POLLUTION}

Understanding genetic variation in environmental response genes $^{92}$ would help us to understand the underlying biology, variability and pathogenesis; identify at risk individuals through DNA based diagnostics; provide information about prognosis; predict pharmacogenomic responses; and develop novel prevention and treatment. ${ }^{193}$ A particular example of a pharmacogenomic response would be the effect of antioxidant supplementation to prevent the effects of air pollution exposure in high risk individuals. This approach of targeting "high risk" individuals is likely to be more efficacious and cost effective than a "population" approach, because of the greater magnitude of harm from air pollution in "high risk" individuals. Antioxidant supplementation has been shown in two prospective randomised controlled trials to reduce ozone induced decrements in lung function in healthy adults ${ }^{94}$ and children with asthma. ${ }^{95}$ Thus maximal benefit could be achieved by targeting chemoprevention, such as vitamins $\mathrm{C}$ and $\mathrm{E}$, in individuals who have known risk factors (eg, respiratory disease) and who are most genetically susceptible (eg, low antioxidant enzyme function due to polymorphism ${ }^{63}$ ). The potential beneficial effects of chemoprevention against the harmful effects of air pollution in subgroups of individuals 


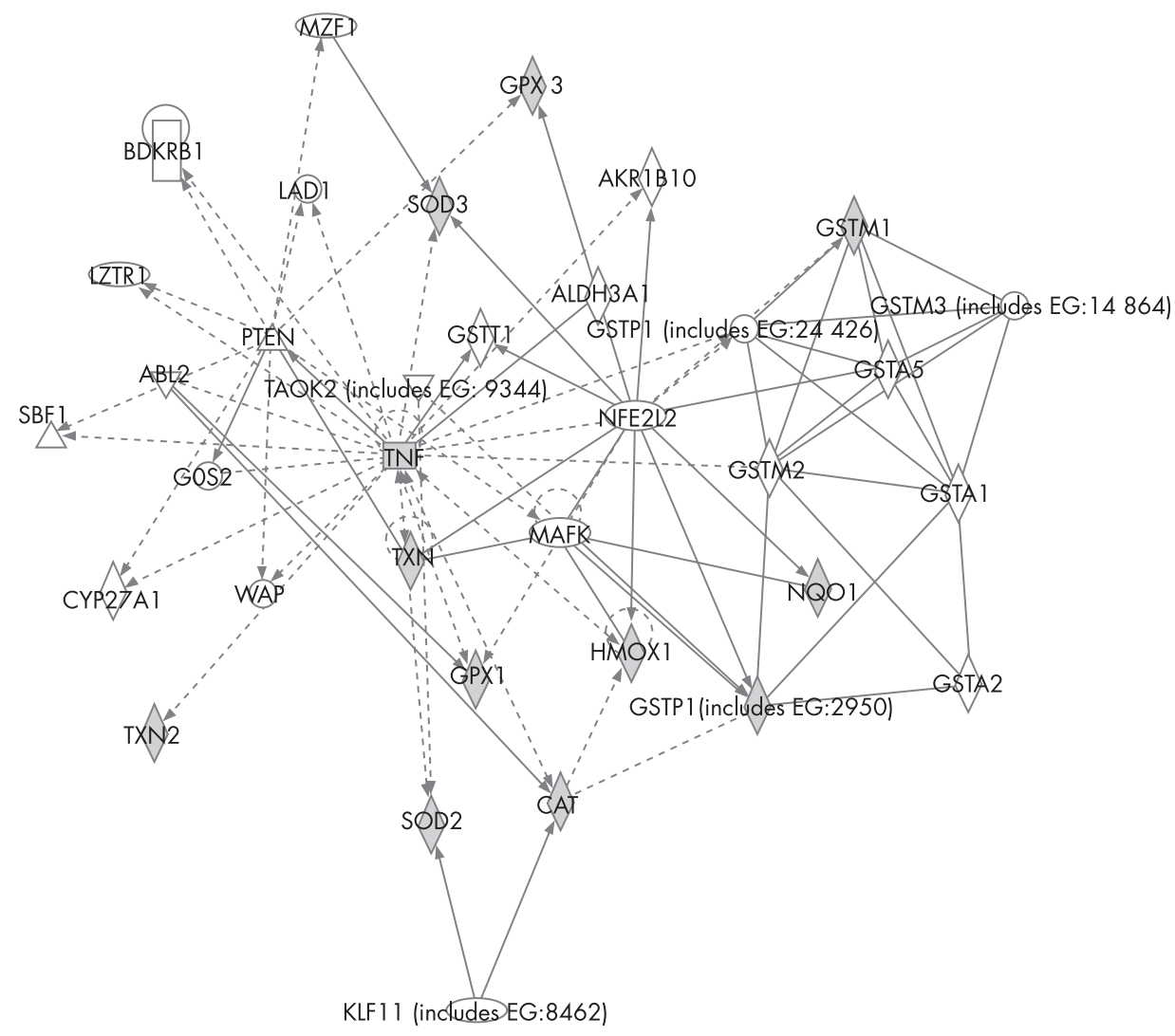

Figure 1 Pathway networks of candidate genes for susceptibility to the respiratory effects of air pollutants. To identify potential candidate genes for future study, pathway networks were generated through the use of Ingenuity Pathways Analysis 4.0 (Ingenuity Systems, Redwood City, CA, USA; available at www.ingenuity.com). Genes showing positive associations with respiratory effects of air pollutants (see table 1: NO01, GSTM1, GSTP1, $T N F$ ) were entered, in addition to candidates based on known antioxidant pathways in the lungs. ${ }^{100}$ The pathway network analysis produced is a graphical representation of molecular interactions between candidate genes and related antioxidant genes. Grey nodes indicate the candidate genes entered into the pathway analysis, solid grey lines indicate direct relationships between genes, broken grey lines indicate indirect relationships between genes. ABL2, v-abl Abelson murine leukaemia viral oncogene homologue 2; AKR1B10, aldo-keto reductase family 1, member B10 (aldose reductase); ALDH3A1, aldehyde dehydrogenase 3 family, memberA1; BDKRB1, bradykinin receptor B1; CAT, catalase; CYP27A1, cytochrome P450, family 27, subfamily A, polypeptide 1; GOS2, G0/G1switch 2; GPX1, glutathione peroxidase 1; GPX3, glutathione peroxidase 3 (plasma); GSTA1, glutathione Stransferase A1; GSTA2, glutathione S-transferase A2; GSTA5, glutathione S-transferase A5; GSTM1, glutathione S-transferase M1; GSTM2, glutathione S-transferase M2 (muscle); GSTM3, glutathione S-transferase, mu 3; GSTP1, glutathione-S-transferase, pi 1; GSTT1, glutathione S-transferase theta 1; HMOX1, haeme oxygenase (decycling) 1; KLF11, Kruppel-like factor 11; LAD1, ladinin 1; LZTR1, leucine-zipper-like transcription regulator 1; MAFK, vmaf musculoaponeurotic fibrosarcoma oncogene homologue K (avian); MZF1, myeloid zinc finger 1; NFE2L2, nuclear factor (erythroid-derived 2)-like 2; NO01, NAD(P)H dehydrogenase, quinone 1; PTEN, phosphatase and tensin homologue; SBF1, SET binding factor 1; SOD2, superoxide dismutase 2, mitochondrial; SOD3, superoxide dismutase 3, extracellular; TAOK2, TAO kinase 2; TNF, tumour necrosis factor; TXN, thioredoxin; TXN2, thioredoxin 2; WAP, whey acidic protein.

would need to be replicated in large prospective randomised controlled trials of both "susceptible" and "resistant" subjects, before chemoprevention could be recommended for clinical use.

\section{SUGGESTIONS FOR FUTURE GENETIC STUDIES OF AIR POLLUTION}

The key objectives of gene-environmental studies of air pollution are to ascertain both exposure to air pollutants and their effects, and their interaction with genetic risk factors. It is recognised that assessment of exposure to outdoor pollutants is complex, with ozone and particulate matter being just components of complex mixtures of air pollutants including, but not limited to, strong oxidants. ${ }^{96}$ Therefore, hypothesis driven studies should be more comprehensive, including the other arm of gene-environment interactions (ie, exposure itself), without which susceptibility cannot be defined.

At present, it would seem that association studies are the most productive strategy in humans. Large prospective studies are preferred, incorporating either biologically relevant candidate genes in a pathway (see fig 1, showing pathway networks between candidate genes, using Ingenuity Pathways Analysis) or, where possible, whole genome association studies, rather than small, underpowered studies of single genes. Genetic approaches should be applied to study designs of relevance to air pollution, using the principles outlined above for selection of genes and phenotypes, for robust observational and experimental study design. The major types of study designs include observational studies (panel cohort studies), experimental studies (controlled exposure and in vitro studies) and clinical trials (table 2), which have specific advantages and limitations. ${ }^{97}$

Observational

- Panel cohort studies, in which lung function or respiratory symptoms are prospectively measured in individuals and compared with daily air pollution levels. These studies could be performed in various settings throughout childhood and adult exposure, and also in utero (through maternal exposures) when maternal genetic modifiers of fetal 
Table 2 Suggestions for study designs for genetic susceptibility to the respiratory effects of air pollution in humans

\begin{tabular}{|c|c|c|}
\hline $\begin{array}{l}\text { Study design to which genetics } \\
\text { can be included }\end{array}$ & Advantages & Limitations \\
\hline \multirow[t]{4}{*}{ Panel cohort study } & $\begin{array}{l}\text { Prospective measurement of a range } \\
\text { of air pollutants }\end{array}$ & Individual clinical data may not be available \\
\hline & Larger sample sizes possible & $\begin{array}{l}\text { Possibly smaller effect sizes (population } \\
\text { based) }\end{array}$ \\
\hline & Longer time course possible & Confounding factors present \\
\hline & & Difficult to assess biological phenotypes \\
\hline \multirow[t]{3}{*}{$\begin{array}{l}\text { Controlled exposure study of } \\
\text { volunteers }\end{array}$} & $\begin{array}{l}\text { Controlled environment and population, } \\
\text { reduces confounders }\end{array}$ & Generally smaller sample sizes \\
\hline & Can study high risk populations & Multiple pollutants usually not studied \\
\hline & $\begin{array}{l}\text { More practical to assess biological } \\
\text { phenotypes }\end{array}$ & Relatively short time course \\
\hline \multirow[t]{4}{*}{$\begin{array}{l}\text { In vitro experiments of biological } \\
\text { samples from volunteers }\end{array}$} & $\begin{array}{l}\text { Controlled environment and population, } \\
\text { reduces confounders }\end{array}$ & Generally smaller sample sizes \\
\hline & $\begin{array}{l}\text { Detailed mechanistic study possible (eg, } \\
\text { gene expression microarrays, proteomics) }\end{array}$ & Relatively short time course \\
\hline & & May not entirely reflect in vivo situation \\
\hline & & Requires biological samples to be obtained \\
\hline \multirow[t]{3}{*}{ Randomised controlled trial } & Prospective interventional trial & $\begin{array}{l}\text { Often need larger sample sizes and longer } \\
\text { duration to show a clinically important } \\
\text { difference }\end{array}$ \\
\hline & Can target high risk individuals & $\begin{array}{l}\text { Needs replication to be generalisable to other } \\
\text { settings }\end{array}$ \\
\hline & Directly applicable to clinical practice & \\
\hline
\end{tabular}

exposure $^{98}$ or even epigenetic effects of air pollutants may be important. ${ }^{99}$

Experimental

- Controlled exposure studies of volunteers, in which lung function and airway cells and mediators are measured.

- In vitro cell culture studies of air pollutant exposure, where cells have been obtained from volunteers.

Clinical trials

- Randomised controlled trials of interventions against the adverse effects of air pollution, in susceptible individuals during periods of high risk exposures.

\section{CONCLUSIONS}

In summary, genetic association studies have been the most feasible study design for investigating the interactions between genetics and the adverse effects of air pollutants in humans. The majority of human genetic association studies of air pollutants have examined ozone exposure, and the greatest effect has been on lung function. Polymorphisms in oxidative stress genes (NQO1, GSTM1, GSTP1) increase respiratory symptoms, lung function, biomarkers and risk of asthma. Inflammatory gene polymorphisms (TNF) influence the lung function response to ozone, and the risk of developing asthma depending on ozone levels. Polymorphisms in oxidative stress genes (GSTM1, GSTP1) alter the response to combined exposure to ragweed pollen and diesel exhaust particles. Genetic linkage studies have not been feasible in human families but some progress has been made in studies of specially bred mice, which have identified chromosomal regions linked to the effects of exposure to ozone or particles. Importantly, polymorphisms in risk genes have been shown to predict which patients with asthma benefit from antioxidant supplementation in areas of high exposure to ozone. Therefore, a high priority now is, in addition to avoiding exposure in the most susceptible people, to clearly identify the most effective and safe chemopreventive agents for individuals who are genetically susceptible to the adverse effects of air pollution (eg, antioxidants) to be taken during high ozone levels.

Funding: IAY, KMF and PVZ were supported by the National Health and Medical Research Council (Australia). STH is a Medical Research Council (UK) Professor of Immunopharmacology. JWH was supported by the Medical Research Council (UK), The British Lung Foundation, Asthma UK and the Asthma, Allergy \& Inflammation Research Charity.

Competing interests: None.

\section{REFERENCES}

1. Brunekreef B, Holgate ST. Air pollution and health. Lancet 2002;360:1233-42.

2. Viegi G, Maio S, Pistelli F, et al. Epidemiology of chronic obstructive pulmonary disease: health effects of air pollution. Respirology 2006;11:523-32.

3. Künzli N, Kaiser R, Medina S, et al. Public-health impact of outdoor and trafficrelated air pollution: a European assessment. Lancet 2000;356:795-801.

4. Hoek G, Brunekreef B, Goldbohm S, et al. Association between mortality and indicators of traffic-related air pollution in the Netherlands: a cohort study. Lancet 2002;360:1203-9.

5. Annesi-Maesano I, Agabiti N, Pistelli R, et al. Subpopulations at increased risk of adverse health outcomes from air pollution. Eur Respir J Supp/ 2003;40:57s-63.

6. Gauderman WJ, Avol E, Gilliland $F$, et al. The effect of air pollution on lung development from 10 to 18 years of age. N Engl J Med 2004;351:1057-67.

7. McDonnell WF 3rd, Horstman DH, Abdul-Salaam S, et al. Reproducibility of individual responses to ozone exposure. Am Rev Respir Dis 1985;131:36-40.

8. Holz 0, Jörres RA, Timm P, et al. Ozone-induced airway inflammatory changes differ between individuals and are reproducible. Am J Respir Crit Care Med 1999;159:776-84.

9. Kleeberger SR. Genetic aspects of susceptibility to air pollution. Eur Respir J Suppl 2003:40:52s-6.

10. Kleeberger SR. Genetic aspects of pulmonary responses to inhaled pollutants. Exp Toxicol Pathol 2005;57(Suppl 1):147-53.

11. Lander ES, Schork NJ. Genetic dissection of complex traits. Science 1994;265:2037-48.

12. Dawn Teare M, Barrett JH. Genetic linkage studies. Lancet 2005;366:1036-44.

13. Cordell HJ, Clayton DG. Genetic association studies. Lancet 2005;366:1121-31.

14. Campbell H, Rudan I. Interpretation of genetic association studies in complex disease. Pharmacogenomics J 2002;2:349-60.

15. Yang IA, Holgate ST, Holloway JW. Toll-like receptor polymorphisms and allergic disease: interpreting the evidence from genetic studies. Clin Exp Allergy 2004;34:163-6. 
16. Tabor HK, Risch NJ, Myers RM. Opinion: Candidate-gene approaches for studying complex genetic traits: practical considerations. Nat Rev Genet 2002;3:391-7.

17. Botstein D, Risch N. Discovering genotypes underlying human phenotypes: past successes for mendelian disease, future approaches for complex disease. Nat Genet 2003;33(Suppl):228-37.

18. Subramanian G, Adams MD, Venter JC, et al. Implications of the human genome for understanding human biology and medicine. JAMA 2001;286:2296-307.

19. Guttmacher AE, Collins FS. Genomic medicine-a primer. N Engl J Med 2002;347:1512-20.

20. Uysal N, Schapira RM. Effects of ozone on lung function and lung diseases. Curr Opin Pulm Med 2003;9:144-50.

21. Churg A. Interactions of exogenous or evoked agents and particles: the role of reactive oxygen species. Free Radic Biol Med 2003;34:1230-5.

22. Becker S, Fenton MJ, Soukup JM. Involvement of microbial components and tolllike receptors 2 and 4 in cytokine responses to air pollution particles. Am J Respir Cell Mol Biol 2002;27:611-18.

23. Li N, Wang M, Oberley TD, et al. Comparison of the pro-oxidative and proinflammatory effects of organic diesel exhaust particle chemicals in bronchial epithelial cells and macrophages. J Immunol 2002;169:4531-41.

24. Todd JA. Statistical false positive or true disease pathway? Nat Genet 2006;38:731-3.

25. Cardon LR, Bell Jl. Association study designs for complex diseases. Nat Rev Genet 2001;2:91-9.

26. Lohmueller KE, Pearce $\mathrm{CL}$, Pike $\mathrm{M}$, et al. Meta-analysis of genetic association studies supports a contribution of common variants to susceptibility to common disease. Nat Genet 2003;33:177-82

27. Ioannidis JP, Trikalinos TA, Ntzani EE, et al. Genetic associations in large versus small studies: an empirical assessment. Lancet 2003;361:567-71.

28. Colhoun HM, McKeigue PM, Davey Smith G. Problems of reporting genetic associations with complex outcomes. Lancet 2003;361:865-72

29. Healy DG. Case-control studies in the genomic era: a clinician's guide. Lancet Neurol 2006;5:701-7.

30. Hall IP, Blakey JD. Genetic association studies in Thorax. Thorax 2005;60:357-9

31. Hall IP, Blakey JD, Al Balushi KA, et al. Beta2-adrenoceptor polymorphisms and asthma from childhood to middle age in the British 1958 birth cohort: a genetic association study. Lancet 2006;368:771-9.

32. Lee SL, Wong WH, Lau YL. Association between air pollution and asthma admission among children in Hong Kong. Clin Exp Allergy 2006;36:1138-46.

33. Medina-Ramon M, Zanobetti A, Schwartz J. The effect of ozone and PM10 on hospital admissions for pneumonia and chronic obstructive pulmonary disease: a national multicity study. Am J Epidemiol 2006;163:579-88.

34. Sunyer J, Basagana X, Belmonte $\mathrm{J}$, et al. Effect of nitrogen dioxide and ozone on the risk of dying in patients with severe asthma. Thorax 2002;57:687-93

35. Bell ML, McDermott A, Zeger SL, et al. Ozone and short-term mortality in 95 US urban communities, 1987-2000. JAMA 2004;292:2372-8.

36. Gryparis A, Forsberg B, Katsouyanni K, et al. Acute effects of ozone on mortality from the "air pollution and health: a European approach" project. Am J Respir Crit Care Med 2004;170:1080-7.

37. Filleul L, Cassadou S, Medina S, et al. The relation between temperature, ozone, and mortality in nine French cities during the heat wave of 2003. Environ Health Perspect 2006;114:1344-7.

38. McConnell R, Berhane K, Gilliland F, et al. Asthma in exercising children exposed to ozone: a cohort study. Lancet 2002:359:386-91.

39. Jörres R, Nowak D, Magnussen $H$. The effect of ozone exposure on allergen responsiveness in subjects with asthma or rhinitis. Am J Respir Crit Care Med 1996:153:56-64.

40. Jörres RA, Holz 0, Zachgo W, et al. The effect of repeated ozone exposures on inflammatory markers in bronchoalveolar lavage fluid and mucosal biopsies. Am J Respir Crit Care Med 2000;161:1855-61.

41. Holz 0, Mücke M, Paasch K, et al. Repeated ozone exposures enhance bronchial allergen responses in subjects with rhinitis or asthma. Clin Exp Allergy 2002; $32: 681-9$.

42. Krishna MT, Madden J, Teran LM, et al. Effects of 0.2 ppm ozone on biomarkers of inflammation in bronchoalveolar lavage fluid and bronchial mucosa of healthy subjects. Eur Respir J 1998;11:1294-300.

43. Stenfors N, Pourazar J, Blomberg A, et al. Effect of ozone on bronchial mucosal inflammation in asthmatic and healthy subjects. Respir Med 2002;96:352-8.

44. Mudway IS, Krishna MT, Frew AJ, et al. Compromised concentrations of ascorbate in fluid lining the respiratory tract in human subjects after exposure to ozone. Occup Environ Med 1999;56:473-81.

45. Avissar NE, Reed CK, Cox C, et al. Ozone, but not nitrogen dioxide, exposure decreases glutathione peroxidases in epithelial lining fluid of human lung. Am J Respir Crit Care Med 2000;162(4 Pt 1):1342-7.

46. Kelly FJ. Oxidative stress: its role in air pollution and adverse health effects. Occup Environ Med 2003:60:612-16.

47. Devlin RB, McKinnon KP, Noah T, et al. Ozone-induced release of cytokines and fibronectin by alveolar macrophages and airway epithelial cells. Am J Physio 1994;266(6 Pt 1):L612-19.

48. Rusznak C, Devalia JL, Sapsford RJ, et al. Ozone-induced mediator release from human bronchial epithelial cells in vitro and the influence of nedocromil sodium. Eur Respir J 1996;9:2298-305.

49. Bayram H, Sapsford RJ, Abdelaziz MM, et al. Effect of ozone and nitrogen dioxide on the release of proinflammatory mediators from bronchial epithelial cells of nonatopic nonasthmatic subjects and atopic asthmatic patients in vitro. J Allergy Clin Immunol 2001;107:287-94.

50. Backus-Hazzard GS, Howden R, Kleeberger SR. Genetic susceptibility to ozoneinduced lung inflammation in animal models of asthma. Curr Opin Allergy Clin Immunol 2004; 4:349-53

51. Kleeberger SR, Levitt RC, Zhang LY, et al. Linkage analysis of susceptibility to ozone-induced lung inflammation in inbred mice. Nat Genet 1997;17:475-8.

52. Cho HY, Zhang LY, Kleeberger SR. Ozone-induced lung inflammation and hyperreactivity are mediated via tumor necrosis factor-alpha receptors. Am J Physiol Lung Cell Mol Physiol 2001;280:L537-46.

53. Shore SA, Schwartzman IN, Le Blanc B, et al. Tumor necrosis factor receptor 2 contributes to ozone-induced airway hyperresponsiveness in mice. Am J Respir Crit Care Med 2001;164:602-7

54. Prows DR, Shertzer HG, Daly MJ, et al. Genetic analysis of ozone-induced acute lung injury in sensitive and resistant strains of mice. Nat Genet 1997:17:471-4.

55. Prows DR, Daly MJ, Shertzer HG, et al. Ozone-induced acute lung injury: genetic analysis of $\mathrm{F}(2)$ mice generated from $\mathrm{A} / \mathrm{J}$ and $\mathrm{C} 57 \mathrm{BL} / 6 \mathrm{~J}$ strains. Am J Physiol 1999;277(2 Pt 1):L372-80

56. Kleeberger SR, Reddy S, Zhang LY, et al. Genetic susceptibility to ozone-induced lung hyperpermeability: role of toll-like receptor 4. Am J Respir Cell Mol Biol 2000:22:620-7.

57. Kleeberger SR, Reddy SP, Zhang LY, et al. Toll-like receptor 4 mediates ozoneinduced murine lung hyperpermeability via inducible nitric oxide synthase. Am J Physiol Lung Cell Mol Physiol 2001:280:L326-33.

58. Bergamaschi E, De Palma G, Mozzoni P, et al. Polymorphism of quinonemetabolizing enzymes and susceptibility to ozone-induced acute effects. Am J Respir Crit Care Med 2001;163:1426-31.

59. Corradi M, Alinovi R, Goldoni M, et al. Biomarkers of oxidative stress after controlled human exposure to ozone. Toxicol Lett 2002:134:219-25.

60. Otto-Knapp R, Jurgovsky K, Schierhorn K, et al. Antioxidative enzymes in human nasal mucosa after exposure to ozone. Possible role of GSTM1 deficiency. Inflamm Res 2003;52:51-5.

61. Larsen JE, Colosimo ML, Yang IA, et al. CYP1A1 lle462Val and MPO G-463A interact to increase risk of adenocarcinoma but not squamous cell carcinoma of the lung. Carcinogenesis 2006;27:525-32.

62. David GL, Romieu I Sienra-Monge JJ, et al. Nicotinamide adenine dinucleotide (phosphate) reduced: quinone oxidoreductase and glutathione S-transferase M1 polymorphisms and childhood asthma. Am J Respir Crit Care Med 2003;168:1199_ 204.

63. Romieu I, Sienra-Monge JJ, Ramirez M, et al. Genetic polymorphism of GSTM1 and antioxidant supplementation influence lung function in relation to ozone exposure in asthmatic children in Mexico City. Thorax 2004;59:8-10.

64. Romieu I, Ramirez-Aguilar M, Sienra-Monge JJ, et al. GSTM1 and GSTP1 and respiratory health in asthmatic children exposed to ozone. Eur Respir $J$ 2006;28:953-9

65. Yang IA, Holz 0, Jorres RA, et al. Association of tumour necrosis factor-alpha polymorphisms and ozone-induced change in lung function. Am J Respir Crit Care Med 2005;171:171-6.

66. Li YF, Gauderman WJ, Avol E, et al. Associations of tumor necrosis factor G-308A with childhood asthma and wheezing. Am J Respir Crit Care Med 2006;173:970-6.

67. Winterton DL, Kaufman J, Keener CV, et al. Genetic polymorphisms as biomarkers of sensitivity to inhaled sulfur dioxide in subjects with asthma. Ann Allergy Asthma Immunol 2001;86:232-8.

68. Bayley JP, Ottenhoff TH, Verweij CL. Is there a future for TNF promoter polymorphisms? Genes Immun 2004;5:315-29.

69. Samet JM, Dominici F, Curriero FC, et al. Fine particulate air pollution and mortality in 20 U.S. cities, 1987-1994. N Engl J Med 2000;343:1742-9.

70. Katsouyanni K, Touloumi G, Samoli E, et al. Confounding and effect modification in the short-term effects of ambient particles on total mortality: results from 29 European cities within the APHEA2 project. Epidemiology 2001;12:521-31.

71. Laden F, Schwartz J, Speizer FE, et al. Reduction in fine particulate air pollution and mortality: Extended follow-up of the Harvard Six Cities study. Am J Respir Crit Care Med 2006:173:667-72.

72. Trenga CA, Sullivan JH, Schildcrout JS, et al. Effect of particulate air pollution on lung function in adult and pediatric subjects in a Seattle panel study. Chest 2006:129:1614-22.

73. Atkinson RW, Anderson HR, Sunyer J, et al. Acute effects of particulate ai pollution on respiratory admissions: results from APHEA 2 project. Air Pollution and Health: a European Approach. Am J Respir Crit Care Med 2001;164(10 Pt 1):18606.

74. D'Amato G, Liccardi G, D'Amato M, et al. Outdoor air pollution, climatic changes and allergic bronchial asthma. Eur Respir Mon 2002;21:30-51.

75. Salvi S, Blomberg A, Rudell B, et al. Acute inflammatory responses in the airways and peripheral blood after short-term exposure to diesel exhaust in healthy human volunteers. Am J Respir Crit Care Med 1999;159:702-9.

76. Nightingale JA, Maggs $R$, Cullinan $P$, et al. Airway inflammation after controlled exposure to diesel exhaust particulates. Am J Respir Crit Care Med 2000;162:1616.

77. Salvi SS, Nordenhall C, Blomberg A, et al. Acute exposure to diesel exhaust increases IL-8 and GRO-alpha production in healthy human airways. Am J Respir Crit Care Med 2000:161(2 Pt 1):550-7. 
78. Pourazar J, Frew AJ, Blomberg A, et al. Diesel exhaust exposure enhances the expression of IL-13 in the bronchial epithelium of healthy subjects. Respir Med 2004;98:821-5.

79. Donaldson K, Stone V, Borm PJ, et al. Oxidative stress and calcium signaling in the adverse effects of environmental particles (PM(10)). Free Radic Biol Med 2003;34:1369-82.

80. Nel AE, Diaz-Sanchez D, Li N. The role of particulate pollutants in pulmonary inflammation and asthma: evidence for the involvement of organic chemicals and oxidative stress. Curr Opin Pulm Med 2001;7:20-6.

81. MacNee W, Donaldson K. Mechanism of lung injury caused by PM10 and ultrafine particles with special reference to COPD. Eur Respir J Supp/ 2003;40:47s-51.

82. Gilmour PS, Rahman I, Donaldson K, et al. Histone acetylation regulates epithelial IL-8 release mediated by oxidative stress from environmental particles. Am J Physiol Lung Cell Mol Physiol 2003;284:L533-40.

83. Takizawa $\mathbf{H}$, Abe $\mathrm{S}$, Ohtoshi $\mathrm{T}$, et al. Diesel exhaust particles up-regulate expression of intercellular adhesion molecule-1 (ICAM-1) in human bronchial epithelial cells. Clin Exp Immunol 2000;120:356-62.

84. Ohtoshi T, Takizawa $\mathrm{H}, \mathrm{Okazaki} \mathrm{H}$, et al. Diesel exhaust particles stimulate human airway epithelial cells to produce cytokines relevant to airway inflammation in vitro. J Allergy Clin Immunol 1998;101(6 Pt 1):778-85.

85. Bayram H, Devalia JL, Sapsford RJ, et al. The effect of diesel exhaust particles on cell function and release of inflammatory mediators from human bronchial epithelial cells in vitro. Am J Respir Cell Mol Biol 1998;18:441-8.

86. Ohtsuka Y, Brunson KJ, Jedlicka AE, et al. Genetic linkage analysis of susceptibility to particle exposure in mice. Am J Respir Cell Mol Biol 2000;22:574-81.

87. Prows DR, McDowell SA, Aronow BJ, et al. Genetic susceptibility to nickel-induced acute lung injury. Chemosphere 2003;51:1139-48.

88. Gilliland FD, Li YF, Saxon A, et al. Effect of glutathione-S-transferase M1 and P1 genotypes on xenobiotic enhancement of allergic responses: randomised, placebocontrolled crossover study. Lancet 2004;363:119-25.
89. Gilliland FD, Li YF, Gong H Jr, et al. Glutathione S-transferases M1 and P1 prevent aggravation of allergic responses by secondhand smoke. Am J Respir Crit Care Med 2006;174:1335-41.

90. Schildcrout JS, Sheppard L, Lumley T, et al. Ambient air pollution and asthma exacerbations in children: an eight-city analysis. Am J Epidemiol 2006;164(:505-17.

91. Kleeberger SR, Zhang L-Y, Jakab GJ. Differential susceptibility to oxidant exposure in inbred strains of mice: nitrogen dioxide versus ozone. Inhal Toxicol 1997;9:60121

92. Christiani DC, Sharp RR, Collman GW, et al. Applying genomic technologies in environmental health research: challenges and opportunities. J Occup Environ Med 2001;:43:526-33

93. Mattick JS. The human genome and the future of medicine. Med J Aust 2003;179:212-16

94. Samet JM, Hatch GE, Horstman D, et al. Effect of antioxidant supplementation on ozone-induced lung injury in human subjects. Am J Respir Crit Care Med 2001;164:819-25.

95. Romieu I, Sienra-Monge JJ, Ramirez-Aguilar M, et al. Antioxidant supplementation and lung functions among children with asthma exposed to high levels of air pollutants. Am J Respir Crit Care Med 2002;166:703-9.

96. Zeka A, Schwartz J. Estimating the independent effects of multiple pollutants in the presence of measurement error: an application of a measurement-error-resistant technique. Environ Health Perspect 2004;112:1686-90.

97. Bernstein JA, Alexis N, Barnes C, et al. Health effects of air pollution. J Allergy Clin Immunol 2004;114:1116-23.

98. Carroll WD, Lenney W, Child F, et al. Maternal glutathione S-transferase GSTP1 genotype is a specific predictor of phenotype in children with asthma. Pediatr Allergy Immunol 2005;16:32-9.

99. Jirtle RL, Skinner MK. Environmental epigenomics and disease susceptibility. Nat Rev Genet 2007;8:253-62.

100. Kinnula VL. Focus on antioxidant enzymes and antioxidant strategies in smoking related airway diseases. Thorax 2005;60:693-700. 